Fecha de recepción: diciembre 2019 Fecha de aceptación: febrero 2020 Versión final: marzo 2020

\section{Transition Design: An Educational Framework for Advancing the Study and Design of Sustainable Transitions}

Terry Irwin ${ }^{(1)}$, Cameron Tonkinwise ${ }^{(2)}$ and

Gideon Kossoff ${ }^{(3)}$

\begin{abstract}
The following paper aims to purvey some of the design history and theory that is being used by the School of Design at Carnegie Mellon University in its effort to constitute the practice of Transition Design. It will explain how the profession and discipline of design is currently undergoing rapid expansion and transformation that afford a rich set of frameworks for transition design. This paper argues that not only can and should designers learn from transition studies, but that design can contribute reciprocally through new approaches to framing problems related to sociomaterial change within the context of complex ecosystems.
\end{abstract}

Keyswords: Transition Design - Transition Studies - Design history and theory - Sociomaterial change - Complex ecosystems.

[Abstracts in spanish and portuguese at page 65]

(1) Terry Irwin is a Professor in The School of Design and the Director of the Transition Design Institute at Carnegie Mellon University, Pittsburgh. She has been a design practitioner for more than 40 years and was a founding partner of the international design firm MetaDesign. Her research focus is in Transition Design and how principles from living systems and Goethe's approach to understanding natural phenomena can inform more responsible and sustainable design approaches. The Transition Design Institute works with educators, researchers, communities and businesses to develop tools and approaches for seeding and catalyzing systems-level change. tirwin@andrew.cmu.edu

(2) Cameron Tonkinwise is Professor and Director of the Design Innovation Research Centre at the University of Technology,Sydney,Australia Hewas previously director of design studies and doctoral studies at Carnegie Mellon University's School of Design and before that, associate dean sustainability at Parsons. The New School for Design and director of design studies at the University of Technology Sydney. The focus of Cameron's research is Transition Design and sustainable design, in particular, design that enables transitions toward less materialsintense ways of living, such as could be afforded by sharing economies.

cameron.tonkinwise@uts.edu.au 
(3) Gideon Kossoff is a faculty member in the School of Design and Associate Director of the Transition Design Institute at Carnegie Mellon University, Pittsburgh. His research focuses on how the relationships between humans and between the natural environment, humans, and the built/designed world are the foundation for a sustainable society. Gideon holds a PhD in design from the University of Dundee, Scotland. His thesis was entitled "Holism and the Reconstitution of Everyday Life" through which he proposed Transition Design as a new approach to design. His argument is summarized in an essay-book "Grow Small, Think Beautiful," edited by Stephan Harding and published by Floris. gkossoff@andrew.cmu.edu

\section{Introduction}

The emerging fields of sustainability transitions, transition studies and transition management now encompass a community of international researchers primarily from the areas of social and management sciences and related disciplines. However, contributions from the field of design and its relevant sub-disciplines (communication, information, interaction, product, environmental, service and social design and design research) are still relatively rare.

On one hand, this is not surprising since design is considered a relatively new discipline and a comparatively minor practice. Design is often marginalized as utilitarian and/or decorative largely due to its ubiquity -virtually everything we interact with everyday was designed by someone; the clothes we wear, the tools we use and the buildings we inhabit. It is only recently that disciplines such as anthropology and sociology have begun to study material practices, so it is not surprising that transition studies (like most social sciences) is not focused extensively on the realm of 'things'.

On the other hand, the absence of design in transition studies is surprising given that design can be defined as "devising a course of action aimed at changing existing situations into preferred ones" (Simon, 1969). Though design is often perceived solely as the creator / form-giver of 'things" -products, communications and environments- we will show that design has a long and diverse history in aspiring to drive systems-level change. The modern profession of design arose out of the aspiration of European and American modernists, seeking to transition their societies from tradition-bound communities to universally rational modes of living through the redesign of dwellings, workplaces, furnishings, tools and clothing. Contemporary designers have tempered these imposing ambitions, but persist in the belief that design can enable significant changes in lifestyles and ways of working by making certain practices easier, more effective and / or more enjoyable. Good designs become our habitats and habits that can determine future pathways for our societies. All this implies that design can play a more central role in the discourse of transition.

There has been some recent convergence between design and transition studies. On the design side, the sub-discipline of sustainable design expanded from a focus in the 1990s on production-side issues (pollution control, waste minimization, eco-efficiency, sustainable ma- 
terials selection etc.) to include questions of sustainable consumption in the 2000s (which follows the lead of the UN's Marrakech agreements). The aim was to design product service systems that would deliver more comprehensive sustained reductions in ecological impact. This focus on larger scale solutions led designers to develop strategies for 'systems level change' such as 'design for sustainable behavior' (Boks 2012) and has led to discourses and practices close to what is now called sustainability transitions.

From the transition studies side, there has been a recent focus on the everyday sociomateriality aspects of transitions, largely as a result of the incorporation of Social Practice Theory. This 'bridge-work' is associated with the work of Elizabeth Shove, who criticized sustainability discourses for their dependence on models of resource management and advocated instead for interventions into the dynamics of social practices. Along this trajectory, Shove undertook a sociology of the practice of designing (2007) which has prompted some interest in design within the field of transitions research.

It is clear however, that design has much more to contribute. The following paper aims to purvey some of the design history and theory that is being used by the School of Design at Carnegie Mellon University in its effort to constitute the practice of Transition Design (See Figure 7). It will explain how the profession and discipline of design is currently undergoing rapid expansion and transformation that afford a rich set of frameworks for transition design. This paper argues that not only can and should designers learn from transition studies, but that design can contribute reciprocally through new approaches to framing problems related to sociomaterial change within the context of complex ecosystems.

\section{Why Design and Transition?}

\section{How Design Has Evolved}

Design is in a period of unprecedented evolution and transformation and its importance in post-industrial economies is increasing. This rapid, pervasive change coupled with the increasing demand for design-led approaches to problem solving both afford and obstruct transition solutions.

\section{Design's Approach for Solving Complex Problems}

In 1972, planner Horst Rittel identified a class of complex 'wicked' problems that traditional design process was inadequate for addressing (Rittel and Webber 1973). Since then, design practitioners, theorists and researchers have worked to develop tools and methodologies better suited to these 'unsolvable' problems. In particular they have sought to integrate design's core competencies (visualization, prototyping and form-giving) with user-centered, social and generative research methods that continually evolve in parallel with a deeper understanding of the dynamics of social complexity (Dubberly 2008).

Within the contemporary design context, wicked problems can be understood as ill-de- 
fined, complex systemic problems that emerge from multiple root causes and become interconnected and interdependent over time, coming to resemble complex, adaptive systems (Jones 2014; Irwin 2011a). Wicked problems are comprised of diverse constituencies and stakeholders with conflicting agendas and concerns and exist at multiple levels of spacio-temporal scale. This type of problem cannot be understood or solved from within a single discipline, and multiple interventions over time are not likely to result in a clear solution(s). Most of the problems identified by transition management researchers share these attributes and could therefore be termed 'wicked' or more accurately, 'ecologies' of wicked problems.

As designers' understanding of complex problems has increased, they have begun to contribute within transdisiciplinary teams to address problems in areas such as transportation, community revitalization and resilience, energy systems, healthcare and policy design (Jones, 2014; Junginger, 2014; Hughes et al. 2009). Designers are now the drivers of strategy and innovation for business and are contributing within the social sectors of governance and policy sectors (Brown 2009; Thackara 2013; Junginger 2014). This evolution has sparked a proliferation of design- related sub-disciplines and new ways of working that include interaction design, experience design, participatory design, co-design, service design and design for social innovation. These new areas can be characterized as a shift from the design of discrete objects and 'things' to relationships, interactions and experiences for and within complex social systems.

Design has changed from an activity often undertaken by an individual professional designer to a highly collaborative, co-design activity that involves a variety of actors, including professional designers, experts from other fields and disciplines and users/co-creators (Manzini 2015). To explain design's expanded field of operation, Richard Buchanan developed a model called the Four Orders of Design (2001) (See Figure 1). Buchanan argued that design had evolved from two original 'orders' or placements for invention/creation; 1) visual communication / graphic design and 2) product/industrial design, to a third and fourth order; 3) actions and interactions and 4) complex systems and environments (which encompass the first three orders).

Although the landscape of design has continued to shift since Buchanan's model was proposed, it remains useful in framing and contrasting design's sub-disciplines (and their concerns and outputs) within a broad context. Jones (2014) developed a similar model (See Figure 1) which traces the evolution of several aspects of design including broad orientation, methods and influences and argues after Buchanan that design has moved from more reductionist, mechanistic mindsets and processes to a holistic, highly collaborative systems approach. 


\section{Design's Evolution: Sub-Disciplines, Attitudes, Methods}

\begin{tabular}{|c|c|c|c|}
\hline $\begin{array}{l}\text { Fint Order Design } \\
\text { Symbolic \& Visual } \\
\text { Communications } \\
\text { (Symbol) }\end{array}$ & $\begin{array}{l}\text { Second Order Design } \\
\text { Material Objects } \\
\text { \& Artifacts } \\
\text { (Object) }\end{array}$ & $\begin{array}{l}\text { Third Order Design } \\
\text { Interactions \& } \\
\text { Process } \\
\text { (Action) }\end{array}$ & $\begin{array}{l}\text { Fourth Order Desizn } \\
\text { Emvironments \& } \\
\text { Systems } \\
\text { (Culture/Systems) }\end{array}$ \\
\hline $\begin{array}{l}\text { Sub-disciplines: Communication \& } \\
\text { Graphic Design }\end{array}$ & $\begin{array}{l}\text { Sub-disciplines: Industrial \& Product } \\
\text { Design. Fashion Design }\end{array}$ & \multirow{4}{*}{ 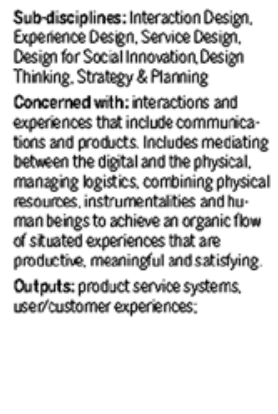 } & \multirow{4}{*}{ 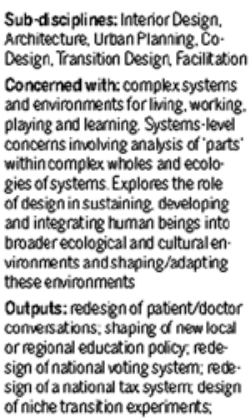 } \\
\hline $\begin{array}{l}\text { Concerned with: the problems of } \\
\text { communicating information. ideas. } \\
\text { arguments through a synthesis of } \\
\text { words and images using a vaniety of } \\
\text { media Motination through argument. }\end{array}$ & $\begin{array}{l}\text { Concerned with: the form function } \\
\text { and appearanoe of everyday objects } \\
\text { and epplores the physical pscholog. } \\
\text { ical, social and cultural relationships } \\
\text { between products and human beings. } \\
\text { Ulsully mass produced. }\end{array}$ & & \\
\hline $\begin{array}{l}\text { Outputs: printed and digital commu- } \\
\text { nicastions of all kinds: Iogas \& identi. } \\
\text { tes: simple websites: onine forms \& } \\
\text { communications. }\end{array}$ & $\begin{array}{l}\text { Usually mass produced. } \\
\text { Outputs: appliances: furniture: } \\
\text { vericles: hand held devices: tools: } \\
\text { medcal equipment; packaging etc. }\end{array}$ & & \\
\hline & & & \\
\hline
\end{tabular}

Evolution of Design's Characteristics From Dubberly et al 2008; Manzini 2015

\begin{tabular}{|c|c|}
\hline 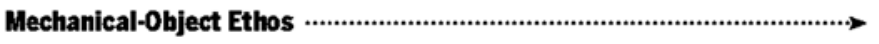 & Organic-Systems Ethos \\
\hline Expert/Disciplinary ................................. & Diffuse/Transdisciplinary \\
\hline Seeks Simplicity & Embraces Complexity \\
\hline Audience: Customers & Audience:Co-Creators \\
\hline Working Toward 'Finish' .................................................................................., & Beta-Friendly Iteration \\
\hline 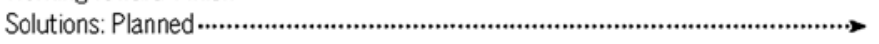 & Solutions: Emergent \\
\hline etary Knowledge & Open Source Knowlec \\
\hline
\end{tabular}

\begin{tabular}{|c|c|c|c|c|}
\hline Generation & First & Second & Third & Fourth \\
\hline Orientation & Rational 1960 s & Pragmatic 1970 s & Phenomenological 1980 s & Generative 2000 s \\
\hline Methods & $\begin{array}{l}\text { Moverment from Craft to } \\
\text { Standardized Methods }\end{array}$ & $\begin{array}{l}\text { Instrumentality. Methods } \\
\text { Customized to Context }\end{array}$ & $\begin{array}{l}\text { Design research and } \\
\text { Stakeholder Methods, } \\
\text { Design cognition }\end{array}$ & $\begin{array}{l}\text { Generative, Empathic and } \\
\text { Transdisicplinary }\end{array}$ \\
\hline Authors \& Trends & $\begin{array}{l}\text { Simon, Fuller, Design } \\
\text { Science Planning }\end{array}$ & $\begin{array}{l}\text { Rittel, Jones, Wicked } \\
\text { Problems evolution }\end{array}$ & $\begin{array}{l}\text { Archer, Norman, User-Cen- } \\
\text { tered Design, Participatory } \\
\text { Design }\end{array}$ & $\begin{array}{l}\text { Dubberly. Sanders, } \\
\text { Generative Design, } \\
\text { Senvice Design }\end{array}$ \\
\hline $\begin{array}{l}\text { Systems } \\
\text { Imfluences }\end{array}$ & $\begin{array}{l}\text { Sciences, Systems Engi- } \\
\text { neening }\end{array}$ & $\begin{array}{l}\text { Natural Systems, Hard } \\
\text { Systems }\end{array}$ & $\begin{array}{l}\text { Systems Dynamics, Social } \\
\text { Systems, Soft Systerns }\end{array}$ & Complexity \\
\hline
\end{tabular}

Figure 1. Design's Evolution: Sub-Disciplines, Attitudes, Methods. 


\section{Design Research}

An important area for the expansion of design into 'transition' scale projects is the field of design research. Designers have evolved beyond their reputation as 'inspiration-based creatives' to work on higher order, increasingly 'wicked' problems that necessitate diverse, comprehensive and creative research methods. Design research has matured to scaffold design practice, enable transdisciplinary collaboration, and is supplementing research in a variety of other disciplines (Martin and Hanington 2012; Koskinen et al. 2011). Research approaches that originate in the social sciences tend to focus on people, their habits, their interactions with each other as well as social norms. Design research studies the qualities of interactions and behaviors that exist between designed artifacts, people and the natural world. In particular it looks at the way in which design can influence and shape human expectations, behavior and practices (Norman 2004; Verbeek et al. 2006) and tends to blur the lines between practice and research. A designer responsible for the concept, design and delivery of products and services often participates in the research to varying degrees.

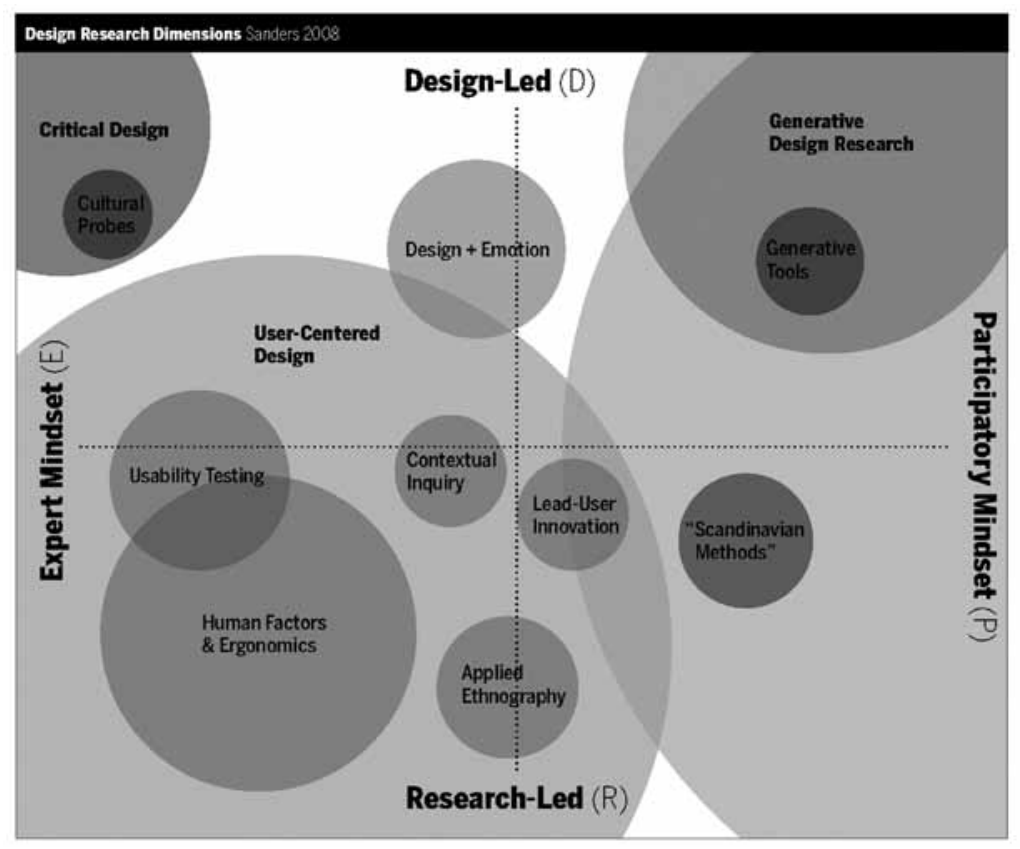

Figure 2a. Sanders'model of design research approaches. 
There is now a well documented body of methods that enable design researchers to collect user- centered data, synthesize and analyze the information, communicate results and design implications and serve to facilitate important conversations with stakeholders, team members, clients and the people who interact with designed products, systems and services. Sanders (2008) has developed a useful overview of design research that contrasts the research dimensions of mindset (expert vs. participatory) and approach (design vs. research led) (See Figure 2a). An overview describing the approaches mapped in figure $2 \mathrm{a}$ is provided in figure $2 \mathrm{~b}$.

\begin{tabular}{|c|c|c|}
\hline RESEARCH DINENSIONS & RESEARCH APPROACH & SOURCES \& INFLUENCES \\
\hline \multirow{2}{*}{ 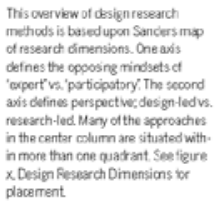 } & 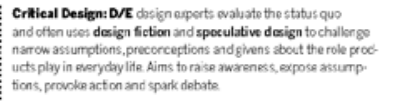 & 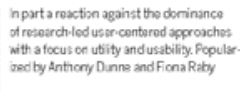 \\
\hline & 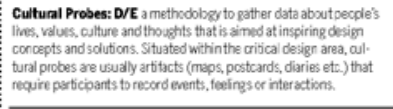 & $\begin{array}{l}\text { Originaly developed ty Gave: Ounne and } \\
\text { Pacentie in } 1999 \text { and inspired by the situa- } \\
\text { fionst art movement. }\end{array}$ \\
\hline \multirow{2}{*}{ 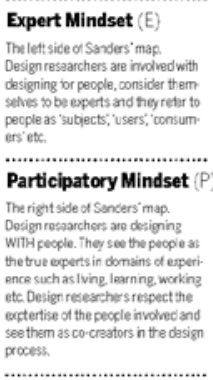 } & 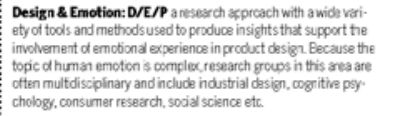 & 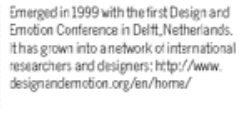 \\
\hline & 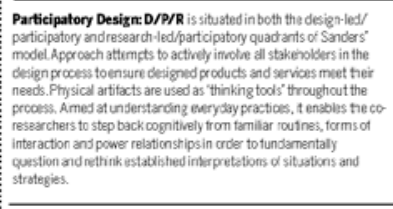 & 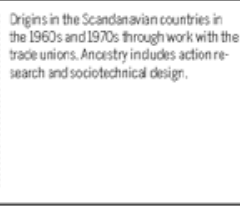 \\
\hline \multirow{4}{*}{ 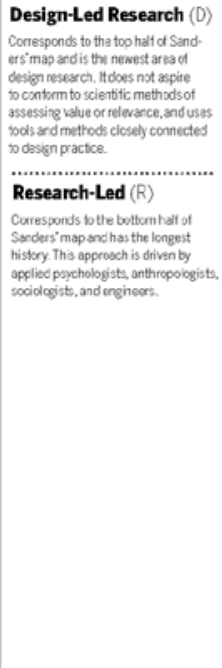 } & 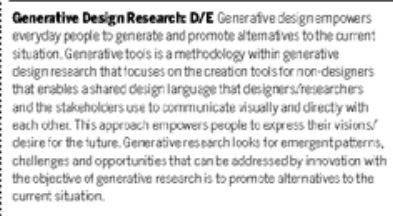 & $\begin{array}{l}\text { See Hanington } 2007 \text {; McCormack et at: } \\
2004 ; \text { Suri } 2008\end{array}$ \\
\hline & 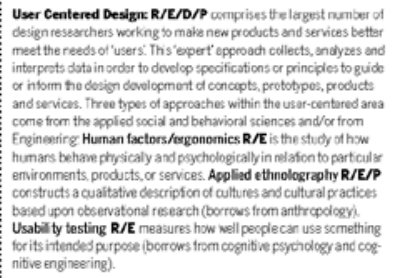 & $\begin{array}{l}\text { Nose out et the products and soltware } \\
\text { destgn disoplines. }\end{array}$ \\
\hline & 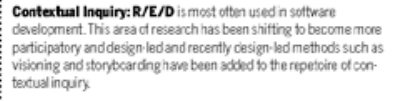 & 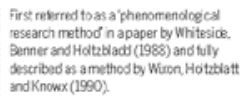 \\
\hline & 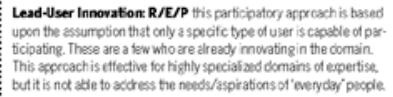 & introduced by ven Hifpel \\
\hline
\end{tabular}

Figure 2b. Table describing Sander's design research dimensions and approaches. 


\section{Areas of Design Focus Particularly Relevant to Socio-Technical Transition Management}

Within an expanded field of operation, there are three areas of established, maturing and emergent design focus that are of particular relevance in socio-technical transition management: Design for Service, Design for Social Innovation and Design for Policy. These areas evolved out of user-centered, participatory and co-design approaches used to understand how people meet their needs and interact with products and services. A growing body of tools, research methodologies and processes are being used by both expert and diffuse designers ${ }^{1}$ in these areas to frame and solve problems at multiple levels of spacio-temporal scale.

\section{Design for Service}

The latter half of the $20^{\text {th }}$. century involved the transition of late capitalist societies from primarily industrial economies to postindustrial societies with strong service economies. Part of this transition involved the emergence of the practice of service design -the planning and organizing of people, infrastructure, communication and material (designed) components of a service to ensure it is user-friendly, productive and even pleasurable for users / customers and that is competitive, profitable and sustainable for the provider (SDN 2015; Saco and Goncalves 2010 ; Forlizzi 2007; Penin 2012; Parker and Heapy 2006; Meroni and Sangiorgi 2011; Polaine et al 2012; Penin and Manix 2012). Service design enables designers and researchers to visualize and prototype new service models in order to understand the functional, aesthetic, emotional, symbolic and social dimensions of the products and services being designed as well as the social behavior that couples and evolves within it. Service design frames problems within large socio-technical contexts that Forlizzi (2013) has described as 'service ecologies.' These are comprised of dynamic relationships between people, products, social activities and infrastructures.

The practice of service design has expanded recently beyond business and for-profit market sectors to not-for-profit and governmental services. Another key area of expansion concerns digital platforms, locational media and social software. These enhance the capacity of services to be automated and/or customized, and facilitate peer-to-peer interactions. In combination with trends toward increasingly dense urban living, service designed systems appear to be lowering material intensity through the decoupling of use and ownership (e.g. car share, etc.) (Manzini 2015; Ceschin 2014).

\section{Design for Social Innovation}

Design for Social Innovation shares and builds on this approach, but because it is explicitly aimed at improving human well-being and livelihood, it is often undertaken within community, non-profit and policy sectors. Manzini (2015) defines social innovations as 
New ideas (products, services and models) that simultaneously meet social needs and create new social relationships or collaborations...they are innovations that are both good for society and enhance society's capacity to act.

Whereas service design tends to operate within business and for-profit models (there are of course exceptions), social design often leads to solutions and interventions that challenge the status quo through the exploration of new modes of exchange and the sharing and pooling of under-utilized social resources (Meroni 2007; Staszowski et al. 2014; Jegou 2015).

\section{Design for Policy}

Policy design evolved out of service and user-centered / participatory approaches in which all stakeholders and constituents are involved in the design process. Within the last decade, design as an approach to policy and service innovation in the public sector has been increasing (Boyer et al. 2011; Cooper et al. 2011; Bason 2013, 2014; Whicher and Swiatek 2015) and Bason has discussed three ways in which design can offer a different approach to policy:

\section{Defining the problem space}

Design research tools including ethnographic, qualitative, user-centered, probes, rapid prototyping and data visualization, can aid policymakers in better understanding the root causes of public problems and their underlying interdependencies or 'architecture of problems' (Boyer et al. 2011; Siodmok 2014)

\section{Developing concepts and ideas for policy}

The collaborative aspects of design research and practice can enable a co-design process among policy constituencies such as interest and lobby groups, external experts and end users such as citizens or business representatives. Visual representations for service and use scenarios can open spaces for negotiation, mutual understanding and collective ownership of ideas. In addition, design approaches enable policymakers and constituencies to envision a desirable future together. Junginger (2014) argues

Designing becomes a means of inquiry and invention, of envisioning and developing new possibilities for useful, usable and desirable policies.

\section{Articulating policy in tangible ways}

Design can help give form to policy in practice through the prototyping and creation of artifacts and communications such as service templates, system maps, identities, products, narratives and the design of all types of information to clarify, direct and explicate. Because design emphasizes human experience in context, it has the potential to highlight values other than the economic and legislative indicators that policy managers typically focus on. Bason and Schneider (2014) have proposed a new role for 'policy designers' and challenge design schools to integrate projects aimed at social change into curricula. They 
also call for designers to begin to work alongside policymakers to develop new approaches aimed at positive societal change.

\section{Designing for Complex Problems: Three Examples}

\section{A Model for Assessing Complexity of Design Problems/Solutions}

With the arrival of practices like service design, design for social innovation and policy design, designers are now operating within much wider scopes and are developing what could be called 'systems interventions'.

In 2013, the Winterhouse Symposium for Education and Social Change (2015) developed a model for mapping change ambitions for social innovation design (See Figure 3a) that can be used in several ways: 1) to envision, map and link projects, interventions and experiments at multiple levels of scale for greater impact; 2) to guide research, design and development; 3 ) as an index for specific skills, resources and partners necessary for a successful project/solution; 4) to assess project outcomes and impacts.

This model has also been useful in illustrating the evolution of design (with its origins in the lower left quadrant, evolving toward the upper right) and mapping the broad/expanding territories in which designers are now working. It also encourages designers to take a meta- level view of even small projects and see them as potentially small steps in larger transitions (from the lower left to. the upper right).

Figure $3 \mathrm{~b}$ shows how a complex problem such as childhood obesity can be addressed using the model. When existing projects and initiatives are mapped onto the matrix (based upon level of scale and range of expertise) new ideas and themes for connecting projects may emerge. A simple solution such as the redesign of a cafeteria tray that guides the portions of food is situated in the lower left where a single designer can contribute a relatively simple solution from within the discipline of product design. Solutions situated in the upper right hand side of the matrix require inter- and transdisciplinary skill sets and teams and are more systemic in their approach, leading to more significant degrees of change. Solutions in the upper right of the matrix often involve the redesign of regional or even national policies and infrastructure and designers contribute from within transdisciplinary teams where they act as catalysts/ facilitators, directing the application of design research approaches.

When existing projects are mapped onto the matrix, it can serve as a guide for designing linkages, replication and partnership for greater leverage. The matrix can also be used as a visioning device to aid teams in planning small interventions that are steps in a mid- and long- term, multi-phased process for change. In such cases, the matrix serves as a roadmap for change at multiple levels of scale, over longer horizons of time. 


\section{Social Design Pathways}

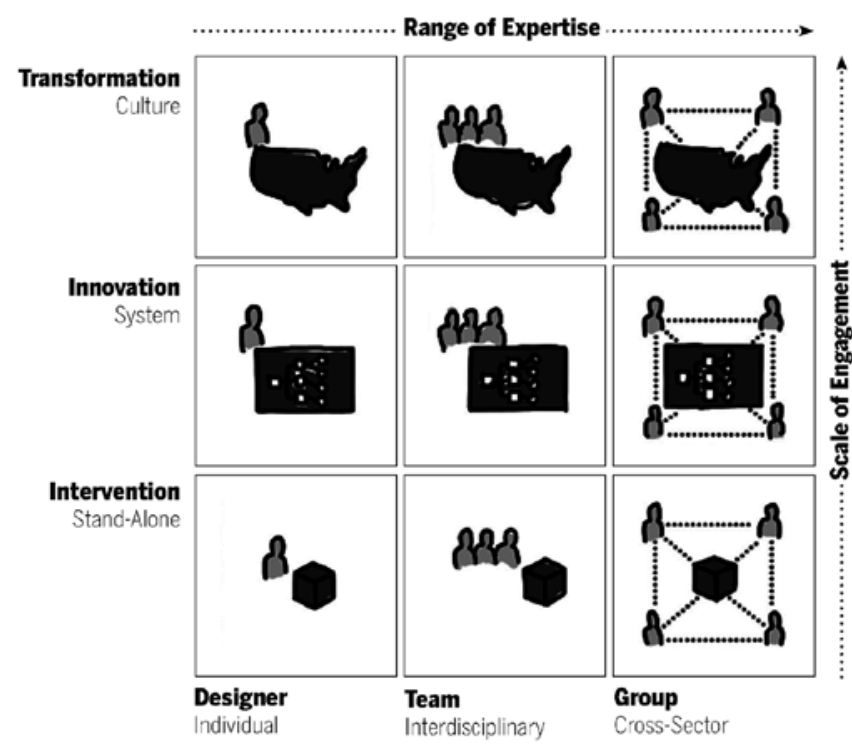

Figure 3a. The

Winterhouse Social

Design Pathways

Matrix maps scales of engagement and the range of expertise required for projects that range from simple to complex.

\section{How can we address childhood obesity?}

\begin{tabular}{|c|c|c|c|}
\hline $\begin{array}{r}\text { Transformation } \\
\text { Cultural, Social, } \\
\text { Economic }\end{array}$ & $\begin{array}{l}\text { Bring public } \\
\text { attention to the } \\
\text { larger problem } \\
\text { Example } \\
\text { Jamie Oliver's Food } \\
\text { Revolution }\end{array}$ & $\begin{array}{l}\text { Change district } \\
\text { food purchasing } \\
\text { policies }\end{array}$ & $\begin{array}{l}\text { Implement } \\
\text { an organic food } \\
\text { standard in the } \\
\text { region/nation }\end{array}$ \\
\hline $\begin{array}{r}\text { Innovation } \\
\text { System }\end{array}$ & $\begin{array}{l}\text { Change the food } \\
\text { display in the } \\
\text { cafeteria line } \\
\text { Eample. } \\
\text { NY Times article } \\
\text { 10.21.2010 }\end{array}$ & $\begin{array}{l}\text { In a single school } \\
\text { students eat } \\
\text { what they grow } \\
\text { Eample. } \\
\text { Edible Schoolyard }\end{array}$ & $\begin{array}{l}\text { Linking local } \\
\text { farms to school } \\
\text { cafeterias } \\
\text { Eample } \\
\text { Farm2School }\end{array}$ \\
\hline $\begin{array}{l}\text { Intervention } \\
\text { Stand-Alone }\end{array}$ & $\begin{array}{l}\text { Cafeteria tray } \\
\text { redesign to guide } \\
\text { food portions } \\
\text { Erandie } \\
\text { Paige Kirstein } \\
\text { (student project) }\end{array}$ & $\begin{array}{l}\text { A Farm Supports } \\
\text { a Community } \\
\text { Eangle: } \\
\text { Corbin Hills } \\
\text { Road Farm }\end{array}$ & $\begin{array}{l}\text { Vacant city lots } \\
\text { become allot- } \\
\text { ment gardens } \\
\text { Example } \\
\text { Southside Commu- } \\
\text { nity Land Trust }\end{array}$ \\
\hline & $\begin{array}{l}\text { Designer } \\
\text { Individual }\end{array}$ & $\begin{array}{l}\text { Team } \\
\text { Intercisciplinary }\end{array}$ & $\begin{array}{l}\text { Group/Partnership } \\
\text { Cross-Sector }\end{array}$ \\
\hline
\end{tabular}

Figure 3b. Shows how designers can use the model strategically and systematically to address a complex problem such as childhood obesity. 


\section{Redesigning the Australian Tax System}

In the mid2000s the Australian Tax Office (ATO) adopted a design-led approach to the development of a new tax administration system. Over the course of several years, design was leveraged in several important ways (Body 2007): to better reflect the government's policy intent; to serve as a bridge between strategy and action; to make paying taxes easier, cheaper and more personalized.

In referencing Buchanan's 4 orders of design, Body noted that the ATO focused on

...the third and fourth orders of design...to ensure that the products and services that it provides will be effective in their interaction with taxpayers... [and] ensure that the whole experience of a tax payer is coherent rather than a mixture of unrelated products and services.

In particular Body underscored the ability of user-centered design approaches to address problems with a high degree of complexity. The ATO went on to develop internal design capabilities and identified three key roles.

1. Design Facilitators who were charged with understanding and overseeing the entire design process and leading the team through discovery, invention and evaluation;

2. Information Designers who were able to work with the emerging data streams and communicate relevant points effectively to the participants via the design of visual representations of discussions, the design process itself and discussion papers;

3. User Researchers who conducted research to identify strategic context for design and user segments, apply techniques for eliciting ideas from users, and to evaluate and identify ideas that warranted further development and production.

Figure 4 shows a range of design tools and techniques developed by the ATO in the redesign of the tax system. The ATO project is an example in which large, infrastructural change was undertaken via a design-led approach. However both expert and diffuse design was present throughout the process and areas of specialty and expertise were continually changing.

\section{Design for Democracy: Redesigning Government Communications}

In the US national elections of 2000, a confusing ballot layout in the closely contested presidential election brought ballot design into the national awareness. According to Lausen (2007):

A government creates trust almost exclusively through communication -using words and images to convey meanings. Most of the communication between a government and its citizens consists of asking for and providing information. These interactions can be positive and engaging experiences, or they can be difficult, frustrating, disengaging ones. The difference is often a matter of communication design. 
She argues that in the realm of government, nowhere is the impact of design greater than in the election process.

\section{Design Tools \& Techniques Used by the ATO Based upon Body 2007}

User Research Conducted research with users early in the design process to better understand the underlying needs of the community and how the ATO should best segment them for design.

User Testing Observed users interacting with products and services to see firsthand how they experienced aspects of the tax system.

Walk-throughs Developed displays of how proposed legislation might work, and taking those displays to major cities with experts on the subject matter to explain and seek feedback from those who might be affected.

Co-design Ran half-day or two-day workshops with ATO staff, affected taxpayers, and other specialists to examine specific workshops issues and develop solutions.

User pathway Represented the results of user research in a way that shows the pathway of a taxpayer group through the tax models system. This usually was an annual pathway. Examples of pathways include youth, wage and salary earners. investors, retirees, and micro, small, medium and large businesses.

Prototyping Involved making something early on that could be shown to people ot guage a response before making a major investment.

Design Created a document that reflected the high-level design of a project, including the intent of the proposed change.

Blueprint the users who would be affected, the new and existing products and services the users would need to interact with; and the processes, technology, and staff changes that would occur.

Core Design Were small groups of people chosen for their specialist knowledge and their predisposition to innovate. People

Teams who can think of all the reasons why something won't work have a role in the design process but not at the core design team stage. The core team was an incubator of fragile ideas, many of which might have seemed radical or unworkable at first. Five people was a good number on the team with some change of personnel occuring as new specialities were needed.

Intent $\quad$ A document intended to produce and document a shared understanding among team members.

Document

Integrated Tax Two diagrams developed to represent the process followed for a project and the way in which multiple projects Design Wheel are able to run concurrently.

and Stacker

Integrated Tax A guide that articulated the process of design in the ATO.It was not prescriptive, but gave some guidance and Design Guide examples and put forward questions that each phase of the design process was aimed at answering.

Debriefs Teams were encouraged to debrief after a design assignment.

Quality Ensured that there was confidence that the process and principles had been followed with the completion of each Assurance phase of a designassignment.

Reviews

Simulation A simulation center was built in Brisbane that allowed the team to observe interactions between taxpayers and Center staff in order to rapidly prototype changes.

Figure 4. Shows the range of design tools and techniques used by the ATO during the redesign of the Australian tax system. 
In the wake of the elections, the American Institute of Graphic Arts (AIGA), one of the nation's largest professional design organizations, launched an initiative to apply design principles to address the need for election reform. What began as a ballot design initiative evolved into the redesign of the entire voting experience. The project team was comprised of design professionals, educators and students as well as experts from many diverse fields. In partnership with the University of Illinois at Chicago's School of Art and Design and election officials in Cook County, Illinois and the state of Oregon, the group developed prototypes designed to improve election administration materials, voting equipment, the polling place environment, absentee and provisional ballots and voter education and outreach. Although communication design was at the heart of a project of this type it also involved the design sub- disciplines of product/industrial design, design research, interaction and service design and design thinking among others.

These three examples attempt to show the levels of scale at which designers are working, the types of complex problems they are engaging with and the range of experts from other fields and disciplines with whom they are collaborating.

\section{Systems Design}

The modern practice of design now encompasses what systems analyst Donella Meadows (2008) has referred to as 'systems leveraging.' She observed that people who are deeply involved in a system often know intuitively where the 'leverage points' for change are but they often push them in the wrong direction because when viewed within our dominant, mechanistic worldview, systems operate in counter-intuitive ways. Meadows listed 12 leverage points for catalyzing change within complex systems and ranked them in reverse order of effectiveness.

Leverage point 12 (the least effective on Meadow's scale) is concerned with changing numbers (increasing / decreasing or doing more or less of something) related to constants and parameters such as subsidies, taxes and standards. Her model references regulating and buffering material flows and driving and balancing positive and negative feedback loops. She observes that once components of a system have taken material form (a highway system, buildings,etc.) it becomes much more difficult to introduce and manifest change. The leverage points with a higher degree of effectiveness have to do with the non-material aspects of a system such as information flows, properties of self-organization within social systems and the specified purpose and goals of the system.

Meadows ranks mindset/paradigm as the single most powerful leverage point for change because the goals, structure, rules and parameters of the system arise out of it. Although paradigms and mindsets are often slow to change Meadows observes

You could say paradigms are harder to change than anything else about a system...but there's nothing physical or expensive or even slow in the process of paradigm change. In a single individual it can happen in a millisecond (Meadows 2008:164). 
Whole societies resist challenges to paradigms and Kuhn (2012) explored this phenomenon in "The Nature of Scientific Revolutions."

Richardson, Irwin and Sherwin in a 2005 report for the UK Design Council, DTI and Defra, developed a continuum of leverage points based upon Meadow's model. Design approaches, opportunities and government policy related to sustainable product design (SPD) in the UK were mapped along the continuum in increasing magnitude of potential impact for change (See Figures 9a and 9b). The authors identified 3 meta-level areas of increasing impact: Changing the design of the products themselves, changing consumption patterns and changing lifestyles. Moving from left to right along the continuum, the importance of future-casting and developing compelling quality-of-life narratives increases.

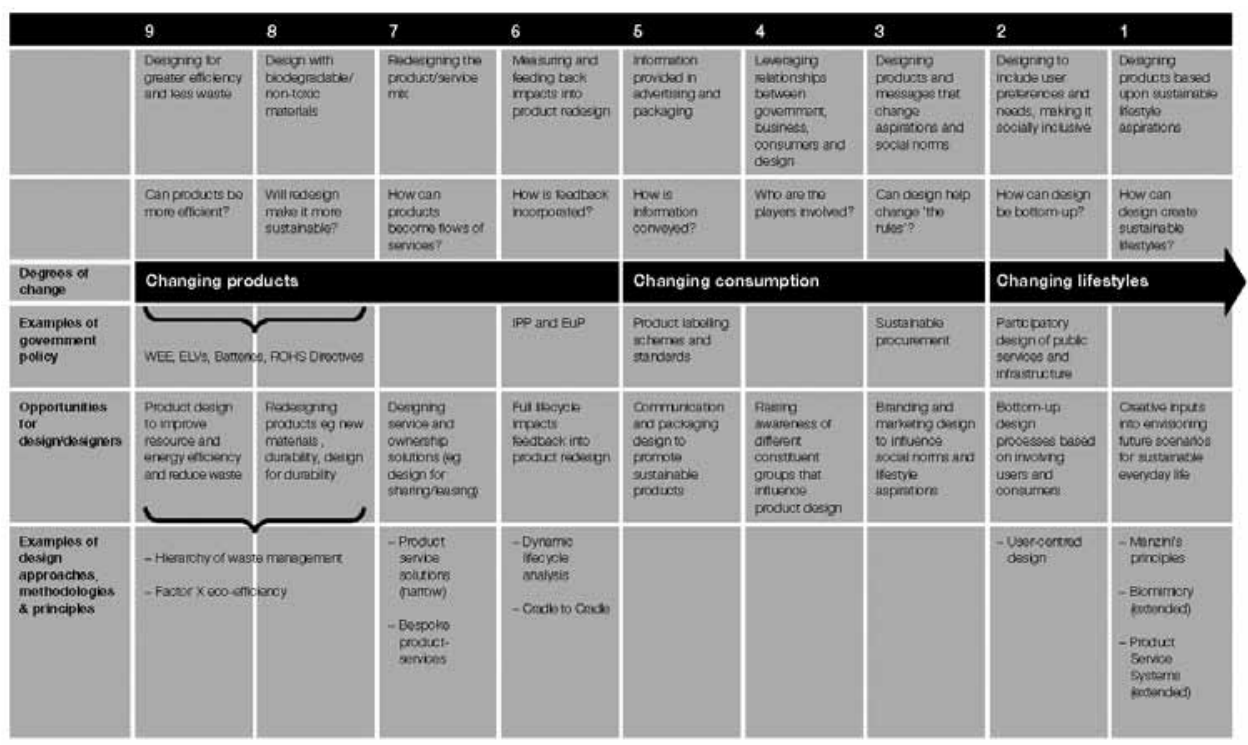

Figure 9a. Richardson, Irwin, Sherwin 2005; “Design and Sustainability: A Scoping Report.” Commissioned by the UK Design Council, Defra and DTI. Available at https://www.academia.edu/4655832/ Design_and_ Sustainability_A_Scoping_Report_UK_Design_Council_DTI_2005 


\section{Leverage Point}

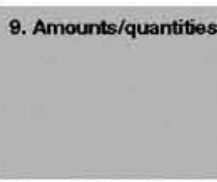

8. Redesign the
structure

7. Stocks relative
to flows

6. Feedback
loops/reduce
delays

5. Information flows

.

4. Critical nodes

3. Changing the rules of the system

2. Self-organisation

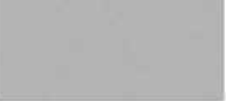

1. Paradigm shift
Changing physical quantities then can be measured and quantified. Much of the envionmental agenda has focussed on this level.

Redefine products and production processes, which determine materials use, emissions and waste.

Changing the ratio of stocks to flows can influence system flexibility and stability.

Working with feedback is about working with inforrnation (consequences/impacts) rather than the physical part of the system. Feedoack loops are more flexible, fluid and responsive than earlier leverage points

Can be thought of as missing feedback loops and providing missing information flows often takes the form of visualizing consequences and impacts.

Locating oritical nodes in a network is crucial for determining the effectiveness of intervention Understan cing what/who constitutes key nodes within a network can help to focus change or leverage opporturities within webs of relationships

Formal and informal rules define the parameters about how the systern works. They can be formal regulations, economic incentives as well as informal social noms and practices.

Systems do not always respond to changes (such as government policy) in predictable ways. They have the capacity to learn adapt and respond creatively in other words, self-organise.

Paradigm refers to the collective 'mind set' of the systern whioh carries with it powertul assumptions. Peradigms can change systems at a fundamental level and can happen in a millisecond.

\section{How it applies to SPD}

Can products be
more efficient?

Will redesign make it more sustainable?

\section{How can products become flows of services?}

How is feedback
incorporated?

\section{How is information} conveyed?

Who are the players involved?

Can design help
change the rules'?

How can design be bottom-up?

\section{How can design} impaot sustainable lifestyles?
This is concerned with reducing amounts of waste, energy and material resources. Meny products' design approaches begin at this level through efficiency, end of pipe and single issue solutions.

This level of change would look at the materials and structure of a product in order to make it more recyclableínon-toxiobiodegradable

Redefining products as flows of services can enhance efficiency through increased flexibility and durability

Environmental and social impacts are measured and treated as feeclback loops to inform redesign of products, services and processes. ICA is an example of visualising impacts to inform product design.

Information about products is conveyed through

actvertising/marketing and on packaging it forms a primary interface with oustomers.

Understanding who the key players are in product development (consumers, government, business and designers) and their push/pull relationship to each other will enable designers to take advantage of opportunities/challenges.

Erand positioning can create perceptionstrends that affect economio parameters and social nomms and affects what a business' product/senvice offer will be.

Bottom-up participatory design processes that involve users/consumers can be creative ways to shitt awareness and behaviour.

Creative design inputs into envisioning future sustainable lifestyles can lead to a complete shift in perception about what is possible and desirable - with consequent impacts on dernends for senvices and goals

Figure 9b. Richardson, Irwin, Sherwin 2005; “Design and Sustainability: A Scoping Report.” Commissioned by the UK Design Council, Defra and DTI. Available at https://www.academia.edu/4655832/ Design_and_ Sustainability_A_Scoping_Report_UK_Design_Council_DTI_2005 


\section{Transition Design}

It is within the context of design's expansion into systems level change that we proposed the notion of Transition Design. Because of this lineage, the 'transition' of Transition Design attempts to draw a more diverse set of precedents than the 'transition' of Transition Studies. The concept of transition is central to a number of contemporary discourses and initiatives concerned with how change manifests and can be catalyzed/directed in complex systems. These discourses are found within academia, non-profit and community sectors but are often unrelated to each other and the field of design. These include sociotechnical transition management and sustainability transitions, the Transition Town Network (Hopkins 2008), The Great Transition Initiative (Raskin et al. 2002) and the concept of transitions in complex systems (Capra 1997; Prigogine and Stengers 1994) to name a few. Transition Design acknowledges and draws from many of these approaches and aspires to be an integrative agent among them. It is proposed as a new area for design research and practice as well as an area of higher education that aims to prepare a new generation of designers qualified to work in transdisciplinary teams on transition solutions.

Transition Design acknowledges that we are living in 'transitional times' and takes as a central premise the need for societal transitions to more sustainable futures. It argues that design has a key role to play in these transitions and applies an understanding of the intercon-nectedness of social, economic, political and natural systems to address problems at all levels of spatio-temporal scale in ways that improve quality of life. Transition Design advocates the reconception of entire lifestyles, with the aim of making them more place-based, convivial and participatory and harmonizing them with the natural environment. A focus is placed the need for 'cosmopolitan localism', (Manzini, 2009; Sachs, 1999) a lifestyle that is place-based and regional, yet global in its awareness and exchange of information and technology. Everyday life is viewed as a potentially powerful, transformative space (Lefebvre, 1984; Gardiner, 2000) where transition designers explore ways in which basic human needs are satisfied locally, within economies that exist to meet those needs (Max-Neef, 1992; Illich, 1987; Kamenetsky, 1992). This is in contrast to the dominant economic paradigm that is predicated upon unbridled growth and an imperative to maximize profit (Korten, 1999. 2010; Mander, 2012; Douthwaite, 1996).

The transition to sustainable futures calls for new ways of designing that are based upon a deep understanding of how to design for change and transition within complex systems (Irwin, 2011). This knowledge and the new skillsets it will inform must be integrated from areas outside design such as science, philosophy, psychology, social science, anthropology and the humanities. This will therefore challenge existing design and design education paradigms.

\section{Transition Design Influences}

Transition Design also draws upon diverse streams of thought from varied fields and disciplines that are relevant to sustainable transitions. These form a fluid and evolving body of knowledge and include: 


\section{Living Systems Theory}

Within the last few decades, scientists within the ecological and biological fields have proposed general principles for how all living systems work (Capra \& Luisi, 2014; Briggs \& Peat, 1999; Prigogine \& Stengers, 1994; Wheatley, 2006). Instead of examining phenomena by attempting to break things down into components, living systems theory explores phenomena in terms of dynamic patterns of the relationships between organisms and their environments. Principles such as self-organization, emergence, resilience, symbiosis, holarchy and interdependence, among others, can serve as leverage points for initiating and catalyzing change within complex systems (Irwin, 2011).

\section{Futuring}

Transition Design proposes that more radically new ideas and compelling visions of sustainable futures are needed. There are myriad approaches to developing future-based narratives that come from the field of science fiction, narrative and storytelling, future-casting / futuring and speculative and critical design to name a few. Transition Design argues that design solutions in the present can be informed by longer-term visions of sustainable futures (Candy, 2014; Dunne \& Raby, 2013; Porritt, 2013; Manzini \& Jegou, 2003).

\section{Indigenous Wisdom}

Indigenous pre-industrial societies lived sustainably in place for generations, informed by 'slow knowledge' that was place-based and embedded within local cultures (Orr, 2004; Papanek, 1995). Transition designers have much to learn from these approaches to designing and their symbiotic relationship with the natural environment.

\section{Cosmopolitan Localism}

Coined by German activist, author and educator Wolfgang Sachs, the term 'cosmopolitan localism' describes a place-based lifestyle in which solutions to global problems are designed for local circumstances and tailored to specific social and ecological contexts whilst being globally connected/networked in their exchange of information, technology and resources (Sachs, 1999; Manzini, 2009, 2015).

\section{Everyday Life Discourse}

Everyday life is an important yet often overlooked context for understanding society and the forces which mold it (Lefebvre, 1984, 1991; Highmore, 2002; Gardiner, 2000). Transition Design proposes that everyday life, and lifestyles, should be the primary context within which to design for sustainable futures and improved quality of life. 


\section{Post Normal Science}

Post normal science is a method of inquiry for addressing long-term issues when relatively little information is available, facts are uncertain, values are in dispute and urgent decisions and outcomes are critical (Ravetz, 2007).

\section{Needs}

Within the context of lifestyles and everyday life, understanding how people go about satisfying their needs is a key strategy for developing sustainable solutions. Manfred MaxNeef's theory of 'needs and satisfiers' (1992) proposes that needs are finite and universal, but the ways in which people meet those needs are limitless and unique to their era, culture, geographic location, age and mindset. Transition Design argues that everyday life is more likely to be sustainable when communities are self-organizing and therefore in control of the satisfaction of their needs at multiple levels of scale: the household, the neighborhood, the city, the region etc. (Kossoff, 2011).

\section{Social Psychology Research}

Since the Rio Earth Summit in 1992, sustainability researchers have tried to establish how best to encourage people to live in more sustainable ways. Social psychology based research, drawn from work on Health Behavior Change (Prochaska and Velicer, 1997), aimed to establish the connection between information and awareness, attitudes and values and behaviors and built environments. Heuristics from this work included 'stages of change,' 'self-efficacy,' 'small steps lead to big steps,' and 'spill-over effect' (Kasser, 2011; Hargreaves et al. 2012).

\section{Social Practice Theory}

Social Practice theory looks at constellations of devices, skills, actions and meanings that form the slow-changing/inertial habits and habitats of everyday life. It designs immersive ethno- graphies to help identify opportunities for innovation in existing practices, and to facilitate the design of multiple interventions that can help create new, more sustainable forms of everyday life (Shove, 2009, 2010).

\section{Alternative Economics}

The transition to sustainable futures will require the development of new kinds of equitable and integrated economic systems in which most needs can be satisfied locally while some remain reliant on global networks. Exploring alternative modes of exchange (outside the dominant economic paradigm) whose objective is the satisfaction of needs for everyone (as opposed to the generation of profit for a few) is an important cornerstone to developing transition solutions (Korten, 1999, 2010; Douthwaite, 1996; Mander, 2012). 


\section{Worldview}

Living in and through transitional times requires a new way of 'being' in the world. Environ- mentalist and physicist Fritjof Capra has argued that the myriad problems confronting society in the 21 st century are interconnected and interrelated and can be traced to a single root problem which is a 'crisis in perception.' He defines this crisis in perception as a mechanistic / reductionist worldview, inadequate for understanding the nature of complex systems. A shift to a more holistic/ecological worldview is one of the most powerful leverage points for transition to sustainable futures (Capra, 1983; Capra \& Luisi, 2014; Clarke, 2002; Toulmin, 1990; Tarnas, 2010; Meadows, 2008).

\section{Goethean Science \& Phenomenology}

Artist and poet Wolfgang von Goethe developed a phenomenological approach to under standing the 'wholeness' of natural organisms, particularly plants. This understanding focused on the temporal dynamics of growth, maturation and demise and looked at the symbiotic, holarchic relationship between part and whole (Bortoft, 1996, 2012; Amrine et al., 1987; Hoffman, 2007; Seamon, 1998).

\section{The Transition Design Framework}

The Transition Design Framework is a fluid, evolving body of knowledge and ideas, often from outside design, whose objective is to provide designers with new tools and methodologies to initiate and catalyze transitions toward more sustainable futures. The framework outlines four mutually reinforcing and co-evolving areas of knowledge, action and self-reflection: 1) Vision; 2) Theories of Change; 3) Mindset \& Posture; 4) New Ways of Designing (See Figure 5).

\section{Vision for Transition}

Transition Design proposes that more compelling future-oriented visions are needed to inform and inspire projects in the present and that the tools and methods of design can aid in the development of these visions. Transition Studies researchers draw on the work of Future Studies research (Dator 2002), especially the process of backcasting - building consensus around a sustainable future vision and then planning backwards to determine how best to get to that objective from our current state. Design has a rich history of future vision-directed designing, especially in the North American tradition (see the work of the Streamliners, Raymond Loewy and Norman Bel Geddes, especially at the New York World's Fair of 1939). However, the contemporary practice of design brings three distinct qualities to Vision for Transition. The first is that designers envision not only desirable futures but also playful or thought-provoking futures. A special practice known as 'Speculative Critical Design' builds plausible but unlikely futures in order to help communities explore what is possible and desirable. The second is that designers build scenarios around near-futures in 
which participants can try out (or imagine themselves trying out) new practices. There is an important relation between niche experimentation in Multi-level Transition Theory and the enactment of design scenarios that needs further research. Thirdly, designers work iteratively, modifying visions of prospective design solutions as they develop a deeper understanding of the problem and detail aspects of the solution. In this way, future visions are motivating, and can even serve as frameworks within which to evaluate design moves, but they nevertheless remain modifiable rather than fixed (situated in the language of Lucy Suchmann 2006).

\section{TRANSITION DESIGN FRAMEWORK}

Four mutually reinforcing and co-evolving areas of knowledge, action and self-reflection

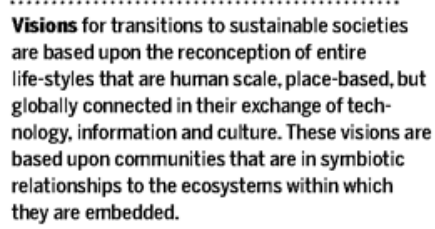

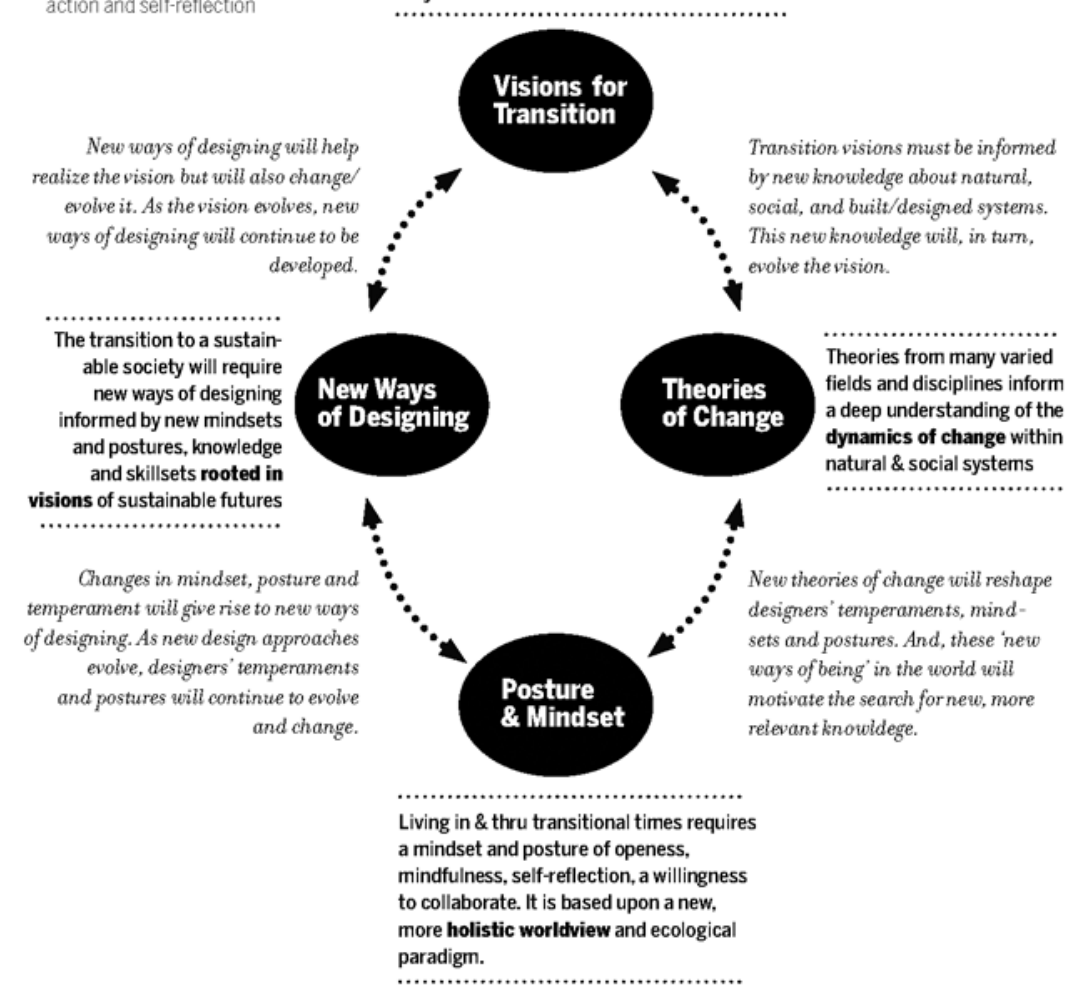

Figure 5. The Transition Design Framework: Irwin, Tonkinwise, Kossoff. 
Transition Design proposes the development of future visions that are dynamic and grassroots based, that emerge from local conditions vs. a one-size-fits-all process, and that remain open-ended and speculative. This type of visioning is a circular, iterative and errorfriendly process used to envision radically new ideas for the future that serve to inform even small, modest solutions in the present. Visions of sustainable futures can provide a means through which contemporary lifestyles and design interventions can be assessed and critiqued against a desired future state and can inform small design decisions in the present. Various design approaches have diversified our ability to imagine the future, and inspire short, mid- and long- term solutions. Examples include Critical and Speculative Design (Dunne \& Raby- 2013; Pierce et al.- 2015; Bardzell et al.- 2014; Michael- 2012) and backcasting and scenario based initiatives such as Manzini and Jegou's Sustainable Everyday (2003) and Jonathon Porritt’s “The World We Made” (2013).

\section{Theories of Change}

Never in history has the need for change been more urgent (Max-Neef 2011). Yet, transfor- mational societal change will depend upon our ability to change our ideas about change itself -how it manifests and how it can be catalyzed and directed. Systems-level, ongoing societal change is inherently transdisciplinary- it must be informed by ideas, theories and methodologies from many varied fields and disciplines.

As a relatively recent discipline, design tends to be practice-based rather than informed by established principles/theory. We have indicated that as design expands its scope into the territory of 'transitions' it has become more research-based. Given the complex and political nature of sociotechnical change, it is important that designers learn to be more explicit about the rationales for their interventions. We therefore insist that Transition Designers work with well-articulated 'Theories of Change.' Theories of Change is a key area within the Transition Design Framework for three important reasons:

1. A theory of change is always present within a planned/designed course of action, whether it is explicitly acknowledged or not;

2. Transition to sustainable futures will require sweeping change at every level of our society;

3. Our conventional, outmoded and seemingly intuitive ideas about change lie at the root of many wicked problems (Irwin, 2011; Scott, 1999; Escobar, 1995).

A new, transdisciplinary body of knowledge is emerging that explains the dynamics of change within complex systems and challenges our current paradigms and assumptions. These ideas have the potential to inform new approaches to design and problem solving. Ideas and discoveries from a diversity of fields such as physics, biology, sociology and organizational development have revealed that change within open, complex systems such as social organizations and ecosystems manifests in counter-intuitive ways. And, although change within such systems can be catalyzed and even gently directed, it cannot be 
managed or controlled, nor can outcomes be accurately predicted (Capra \& Luisi, 2014; Wheatley, 2006; Meadows, 2008; Briggs \& Peat, 1990; Prigogine \& Stengers, 1994).

\section{Posture and Mindset}

Living in and through transitional times calls for self-reflection and new ways of 'being' in the world. Fundamental change is often the result of a shift in mindset or worldview that leads to different ways of interacting with others. Our individual and collective mindsets represent the beliefs, values, assumptions and expectations formed by our individual experiences, cultural norms, religious and spiritual beliefs and the socio-economic and political paradigms to which we subscribe (Capra, 1997; Kearney, 1984; Clarke, 2002).

Designers' mindsets and postures often go unnoticed and unacknowledged but they profoundly influence what is identified as a problem and how it is framed and solved within a given context. Transition Design asks designers to examine their own value system and the role it plays in the design process and argues that solutions will be best conceived within a more holistic worldview that informs more collaborative and responsible postures for interaction. Transition Design examines the phenomenon of mindset and worldview and its connection in wicked problems (Kearney, 1984; Linderman, 2012; Tarnas, 2010; Capra and Luisi, 2014; Irwin, 2011a). Figure 6 contrasts the dominant worldview/mindset with a more holistic one that would inform new postures and approaches to designing.

\section{New Ways of Designing}

When the three previous areas (visions, theories of change and new mindsets/postures) are brought to bear on Service Design, Design for Social Innovation and Design for Policy, it constitutes 'new ways of designing' for transitions.

Transition Designers work in three broad areas:

1. They develop powerful narratives and visions of the future or the 'not yet' (Bloch, 1995; de Sousa Santos, 2006).

2. They amplify and connect grassroots efforts undertaken by local communities and organizations (DESIS, 2009; Manzini, 2003, 2015). Service design or social innovation solutions can be steps within long-term transition solutions. 3. They collaborate in transdisciplinary teams to design new, innovative and place-based solutions rooted in and guided by transition visions.

Although Transition Design can be considered a distinctive way of designing, it is complementary to other design approaches such as design for service and design for social innovation. Designers have the ability to contribute along a spectrum that ranges from design within existing paradigms (in which design is practiced primarily within the commercial marketplace) to design of and for radically new paradigms that challenge the status quo and are based upon equity and quality of life. 
Mindset (Worldview \& Values)

Dominant

World Metaphor. World as amachine, 'parts' and are
separate and independent of each other.

Human Presence: humans are viewed as separate from, and superior to, other forms of life and the natural environment.

Nature: is viewed as a storehouse of resources for human use and consumption.

Timeframe: Conceives actions in short horizons of time with the welfare of self and present generation in mind.

Environmental \& Social Crises. (if acknowledged) are viewed as things that can be foved within existing socio economic political paradigms through technol ogy, economic growth and business as usual:

Individual vs. Community. focus is placed on the individual and their own self fulfillment with an emphasis on material wealth/possesions.

Business \& Economy. are viewod as the context for everyday life. Focus placed on career, eaming power and personal identity/reputation. Disciplinary exper tise and individual achievement is highly prized.

Problem Solving: focuses on individual parts (de contexualization), emphasizes and values disciplinary expertise, strong belief in linear cause and effect outcomes, predictability and control and priviledges quantifiable and replicable results.

\section{Competition vs. Cooperation: belief in competi} tion and proprietary knowledge as the pathway to success. Effective action and solutions take place within the dorninant, single bottom line economic paradigm/marketplace.

Predictability \& Control: sees lack of order and chaos as a problematic and something to be 'fixed" Pre conceived solutions based upon predicted outcomes are imposed ' within top down, often centralized structures.

\section{Ambiguity \& Uncertainty viewed as an undesirable} state and/or as a problem to be solved.

Designers' Role: designers see themselves as expert
practitioners and problem solvers, working alone or
in positions of leadership within cross disciplinary
teams.

Pace: emphasis on face paced processes that arrive at solutions quickly and efficiently, time is money.

\section{Holistic}

World Metaphor. World as aliving organism, "parts' are self organizing, interdependent, mutually influencing and reinforcing and co evolving.

Human Presence: humans are viewed as part of an interdependent web of life that includes other species and the natural environment.

Nature. is viewed as the context for human life, human health is directly connected to the health of the natura environment.

Timeframe: Conceives actions in long horizons of time with the welfare of present and future generations in mind.

Environmental \& Social Crises are viewed with optimistic grumpiness, dissatisfaction with status quo and a sense of urgency combined with the belief that positive change is possible but only within new. alternative paradigms.

Individual vs. Community focus is placed on cammunity and fulfillment through interdependence, reciprocity and belonging

Business \& Economy: everyday life is viewed as the primary context for problem solving. Business and the economy exist to satisfy human needs, without com promising the ability of other species/ future genera tions to meet theirs. Focus placed on quality of life and the bonds of community. Disciolinary expertise is best realized through trans/cross disciplinary collaboration.

Problem Solving focuses on understanding the whole system (context) in order to solve for a part, emphasiz es transdisciplinary collaboration and understanding the emergent (and therefore unpredictable) properties of social and natura systems, priviledges qualities and values.

Competition vs. Cooperation : belief in cooperation and open source information//nowledge ('the com mons"). Effective action and solutions are conceived within alternative economic models.

Predictability \& Control. sees chaos as a rich bed of possibilities where new forms of order and behavio arise spontaeously and unpredictably at the grass roots level. These dynamics can be leveraged/amplified in the formulation of solutions but change cannot be predicted or controlled.

Ambiguity \& Uncertainty: viewed as a natural comoo nent of the process of change within social and natural systems.

Designers' Role designers see themselves as change agents and catalysts for positive social/environmen tal change in a co design process that involves both leadership and followership.

Pace: emphasis on a slower, mindful approach and consensus building with multiple constituencies. Focus on development of longer term solutions.
Posture (Approach)

\section{New}

\section{Posture of humility, reverence for nature and}

acknowledgement of human ignorance (we can never fully understand or 'manage' complex natural or social systems); any action may have unseen short and long term ramifications. Actions and solutions are conceived with welfare of the natural world and future generations in mind.
Posture of action and sense of urgency tempered with patience to carefully observe short term ramifications of actions and consider their long-term implcations. Commitment to the development of radically alternative socio econorric political forms.

Willingness and desire to collaborate and foster positive interactions among groups is seen as an essential stoill.

Commitment to balance in one's own life and others' lives. Ability to collaborate effectively in transdisciplinary groups is seen as a vital skill and source of satisfaction/reward.

Embraces transdisciplinary knowledge and collaboration as the optimumbasis for coordinated action. and problem solving. Involves posture of tinkering or 'shepherding' solutions into existence.

Commitment to sharing information and knowledge as the basis for improving conditions of the whole (so ciety and the environment). Generosity and sharing are seen as essential attributes.

Posture of watchful anticipation and willingness to look for the clues for how to act in the system itself. Trust that the seeds of solutions are already present in what is peroeived as chaos

\section{Posture of flexibility and comfort with uncertainty} combined with a desire to be grounded, yet open to new ideas and ways of acting

Posture of humility and an openess to both lead and beled, commitment to be aware of when one has stepped out of one's domain of expertise.

Posture of patience and a willingness to learn and acknowledge what one doesn't not know.

Figure 6. Irwin, Design and Culture Journal, July 2015. Contrasting existing vs. new postures \& mindsets. 
Figure 7 shows three areas of design focus (Design for Service, Social Innovation and Transition Design) situated along a continuum in which project horizons of time, depth of engagements and socio-economic and political contexts increase as we move from left to right. Service Design is situated on the left and involves expert designers working on short-term, multi-stakeholder projects, primarily within the business and consumer marketplace. Social Innovation occupies a position further along the continuum where projects are usually situated within social and community contexts, engagements are ideally longer and solutions begin to challenge existing socio-economic and political paradigms.

\section{A Continuum of Design Approaches}

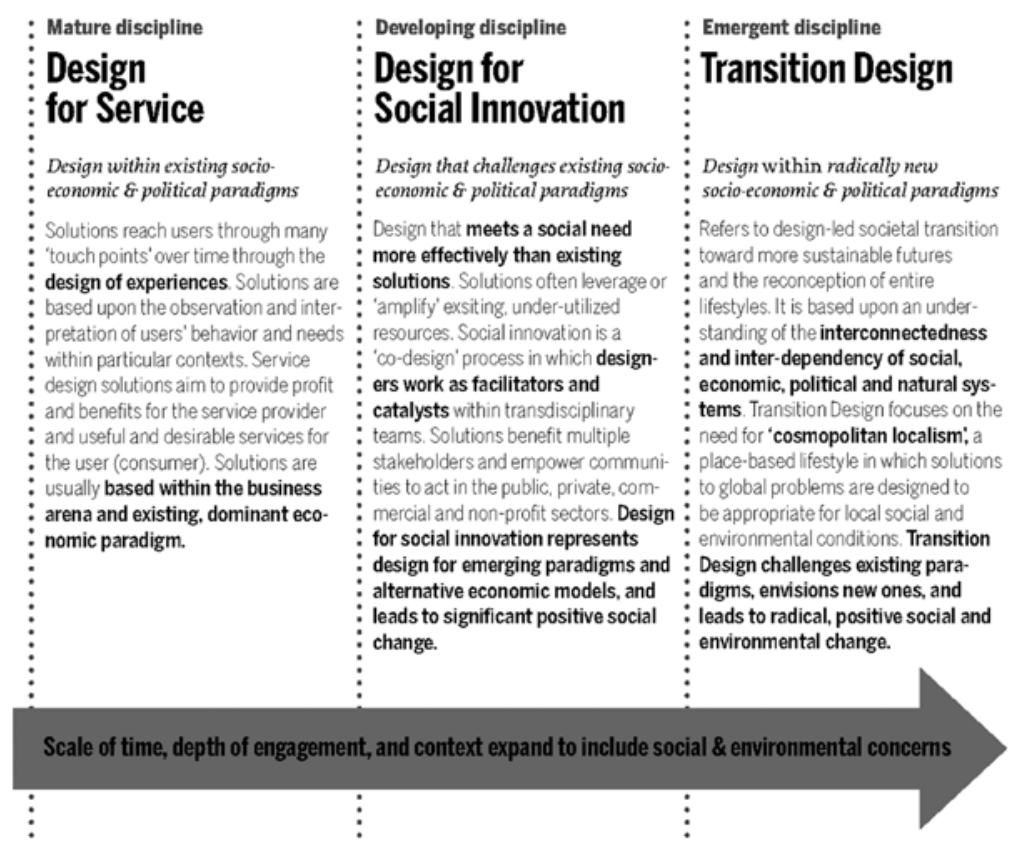

Figure 7. Continuum of design approaches. Irwin 2015. 
Transition design can be positioned at the right end of the continuum where speculative, long-term visions of sustainable lifestyles fundamentally challenge existing paradigms and serve to inspire and inform the design of 'short' and mid-term solutions. Transition design solutions have their origins in long-term thinking, are lifestyle-oriented and placebased and always acknowledge the natural world as the greater context for all design solutions. Transition visions could serve as 'leverage points' within projects undertaken in the service and social innovation sectors by networking and linking them together so that they form steps within a longer transition toward a desired future.

\section{Distinguishing Features of Transition Design(ers)}

Designers working within the social innovation space have developed important new approaches drawn from sociology, organizational science and business (to name a few) and these can and should be expanded and deepened in the emerging area of transition design. This type of work requires a commitment to on-going learning and personal change as well as a kind of 'stick-to-itiveness'; a commitment to change the system through multiple, iterative interventions and the tenacity to persist and change with it, over time. Transition design is distinct from service design or social innovation design in its deep grounding in future-oriented visions, its transdisciplinary imperative, its understanding of how to initiate and direct change within social and natural systems and its emphasis on the temporality of solutions.

Transition Design is also characterized by:

- Leveraging living systems theory as an approach to understanding wicked problems and designing solutions to address them.

- Designing solutions that protect and restore both social and natural ecosystems through the creation of mutually beneficial relationships between people, the things they do and make (design) and the natural environment.

- Privileging everyday life and lifestyles as the fundamental context for design solutions.

- Advocating solutions that are place- and ecosystem-based, but connected to global networks to leverage an exchange of knowledge and technology.

- Designing solutions for short, medium and long horizons of time and all levels of scale of everyday life.

- Looking for emergent possibilities within problem contexts and amplifying grassroots solutions already underway (the seeds for solutions are always within the problem space/ context).

- Linking existing solutions together for greater leverage and to serve as steps in a larger transition vision.

- Distinguishing between 'wants/desires' vs. genuine needs and basing solutions on maximizing and integrating satisfiers for the widest range of needs (Max-Neef 1992)

- Viewing the designer's own mindset and posture as an essential component of transition designing; understanding how worldview and posture influences problem finding, framing and solving. 
- Calling for the reintegration and re-contextualization of diverse transdisciplinary knowledge.

\section{Educating for Transition Design}

In fall, 2015, The School of Design at Carnegie Mellon University launched new programs and curricula that begin to integrate Transition Design at the undergraduate, graduate and doctoral levels (See Figure 8).

Design for Interactions is the over-arching programmatic theme and refers to design for the interactions between people (social), the built (designed) world and the environment (natural world). These interactions involve the design of communications, products and physical/digital environments (sub-disciplines). Students apply their sub-disciplinary skills on projects situated within three areas of design focus: Design for Service, Design for Social Innovation and Transition Design. All programs and curricula acknowledge the social and natural worlds as the larger context for all design problems and solutions. A unifying design studies track runs through undergraduate, graduate and doctoral curricula and in addition to history and theory, introduces values, ethics, sustainability and the topic of transition. The School also offers a PhD and professional doctorate (DDes) in Transition Design.

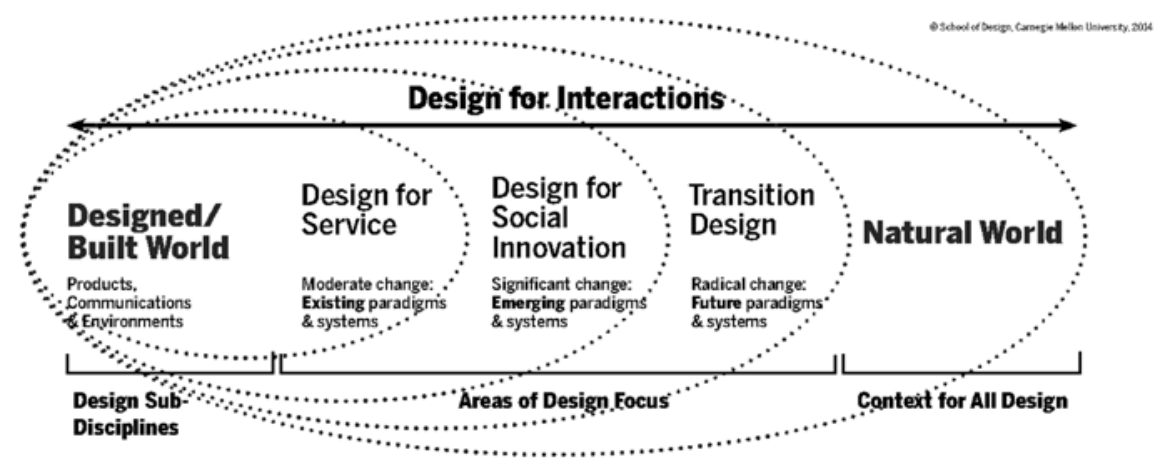

Figure 8. Framework for new design curricula at the undergraduate, graduate and doctoral levels at the School of Design, Carnegie Mellon University. Launched Fall, 2015. 
Transition Design is introduced at the undergraduate level through readings, lectures and studio-based exercises. Masters students conduct design research that informs projects situated in either Design for Service or Design for Social Innovation areas, but within the context of the continuum in figure 7. Doctoral students undertake research in or related to Transition Design and all masters and doctoral students are required to take a semesterlong seminar in the subject.

\section{Teaching Materials}

Within the past year, a number of teaching materials have been developed and are being shared with other design programs around the world with the aim of creating an international network of Transition Design educators. These include a course syllabus and outline for a graduate and doctoral seminar in Transition Design, an extensive bibliography, templates for developing transition design case studies and a number of articles on the subject (Irwin, 2015; Kossoff, 2015; Tonkinwise, 2015). Case studies are based upon the analysis and critique of existing projects/solutions. Using Transition Design principles, designers can evaluate existing projects as the basis for conceptualizing new Transition Design solutions. Part one of the case study critiques an existing project from a transition point of view and part two proposes a transition solution using the original project as the springboard. Transition Design approaches for the critique and design of new solutions include:

\section{Re-conceiving}

The case study is used as the jumping off point for reconceiving the project. Although it may retain many of its original features, the new concept has evolved significantly enough to appear 'new'. The case study's purpose in this example is to spark new thinking that leads to a transition solution.

\section{Connecting/Integrating}

The case study becomes the starting point or 'node' in a network of other projects and relationships that create new synergies and that may spawn new products, services or systems. This approach is akin to seeding and growing an 'ecosystem' in which complementary and symbiotic relationships between entities are part of the act of designing as demonstrated in permaculture design and Zeri Clusters (Capra, 2021 p. 445). In ecosystems, principles of self- organization, emergence and diversity are keys to health and growth. The transition designer looks for and leverages these principles when connecting previously unrelated projects and monitors the system over time to shift, change or refine the connections as needed. 


\section{Amplifying/Leveraging}

The case study is used to create what the philosopher Bakhtin called "the buds and shoots of new potentialities." The transition designer is prompted to look for trends and similar or complimentary projects that already exist that can be connected to leverage or amplify and create a tipping point (Gladwell, 2000; Manzini, 2015) in a planned transition. The "Amplify" project undertaken at Parsons the New School, NYC is an example of how amplifying grassroots efforts can be the foundation for significant change at varying levels of scale (DESIS 2009).

\section{Scaling}

The transition designer sees potential for a project to be scaled in one or more dimensions (up or down), for greater impact. For example, scaling the project over time toward a desired future (through strengthening, expanding, resourcing, etc.), or scaling up from a local to a regional and/or global level or scaling down to become place-based and networked.

\section{Protecting/Restoring}

The case study is used as a lens through which to diagnose the health of relationships present in a project or initiative and its larger context (system). Transition designers assess relationships in the social and environmental spheres and look to improve, protect and/ or strengthen them over time. An example might be designing interventions to restore a local polluted ecosystem or watershed in order to improve the lives of the people in the immediate area. Such a solution must unfold over time (at the speed at which ecosystems are capable of restoring themselves). Small interventions/restorations would be connected to a long-term vision with goals and metrics to measure health, biodiversity, vibrancy of the culture, renewal of local economies, etc.

Case study templates also ask students to map existing projects/initiatives/situations according to project sector, the area(s) of initial design focus, the levels of spatiotemporal scale at which it is designed to exist and asses its potential to become part of a transition solution. Students also map the connections to wicked problems at higher levels of scale and evaluate whether the solution is meeting genuine needs or is based upon pseudo satisfiers or inhibitors (Max-Neef, 1992).

\section{Conclusion}

This paper has argued that designers and the research methods and problem solving approaches they employ have the potential to contribute to solutions in the fields of transition studies and transitions management. The authors have proposed a new area of design study, practice and research-Transition Design. A Transition Design Framework has been developed to enable the introduction of the concept of transition at the undergraduate, graduate and doctoral levels and is being shared with design educators around the world. 
The authors welcome feedback and propose that opportunities for collaboration and research be explored between the design and transition studies/management communities.

\section{Notes}

1. Manzini (2015) makes a distinction between 'diffuse' and 'expert' design. Diffuse design is performed by non-experts with their natural designing capacity, often within the context of other fields and disciplines. Expert design refers to the tools and methodologies that professional designers bring to finding, framing and solving problems.

\section{Bibliography}

Amrine, F.; Zucker, F. \& Wheeler, H. (1987). Goethe and the Sciences: A Reappraisal. Dordrecht (NL): D. Reidel Publishing Company.

Bardzell, J.; Bardzell, S. \& Stolterman, E. (2014). Reading ciritical designs: supporting reasoned interpretations of critical design. In Proceedings of the SIGCHI Conference on Human Factors in Computing Systems. ACM. pp. 1951-1960.

Bason, Ch. (2013). Design-Led Innovation in Government. Stanford Social Innovation Review. Stanford (CA). [accessed July 28]. Spring. http://www.ssireview.org/articles/ entry/ design_led_innovation_in_government.

. (2014). Introduction: The Design for Policy Nexus. In: Bason, C. ed., Design for Policy. Farnham (UK): Gower Publishing Limited. pp. 1-8.

Bason, C. \& Schneider, A. (2014). Public Design in Global Perspective: Empirical Trends. In: Bason, Christian ed., Cooper, Rachel, series ed., Design for Policy. Farnham (UK): Gower Publishing Limited. pp. 23-39.

Bloch, E. (1995). The Principle of Hope. Cambridge (MA): The MIT Press.

Boks, C. (2012). Design for Sustainable Behaviour Research Challenges. In Matusumoto, M.; Umeda, Y.; Masui, K. \& Fukushige, S. (eds.). Design for Sustainable Behaviour Research Challenges. Dordrecht (NL): Springer.

Body, J. (2007). Design in the Australian Taxation Office. Design Issues. 24 (1): 55-67.

Bortoft, H. (1996). The Wholeness of Nature: Goethe's Way Toward a Science of Conscious Participation in Nature. Aurora (CO): Lindisfarne Books.

Boyer, B.; Cook, J.W. \& Steinberg, M. (2011). Recipes for Systemic Change. Helsinki: Sitra.

Briggs, J. \& Peat, D. (1999). Seven Life Lessons of Chaos. New York (NY): Harper Perennial.

Brown, T. (2009). Change By Design. New York: Harper Collins Publishers.

Buchanan, R. (2001). Design Research and the New Learning. Design Issues 17 (4): 3-23.

Candy, S. (2014). Whose Future is This? TEDxChristchurch. Available online [accessed 8.2.15] https://www.youtube.com/watch?v=YxgVxu2mdZI

Capra, F. (1983). The Turning Point: Science, Society and the Rising Culture. New York (NY): Bantam Books. 
Capra, F. (1997). The Web of Life: A New Scientific Understanding of Living Systems. New York (NY): Anchor Books.

Capra, F. \& Luisi, P. L. (2014). The Systems View of Life: A Unifying Vision. Padstow (UK): Cambridge University Press.

Ceschin, F. (2014). Sustainable Product-Service Systems: Between Strategic Design and Transition Studies. London (UK): Springer.

Chapman, J. (2015). Emotionally Durable Design: Objects, Experiences \& Empathy. New York (NY): Routledge. p. 8.

Clarke, M. E. (2002). In Search of Human Nature. London (UK): Routledge.

Dator, J. A. (2002). Advancing Futures: Future Studies in Higher Education. Westport (CT): Praeger Publishers.

de Sousa Santos, B. (2006). The Sociology of Emergences, The Rise of the Global Left: The World Social Forum and Beyond. London (UK): Zed Books.

DESIS Lab. (2009). Amplifying Creative Communities: New York City. New York (NY): Rockefeller Foundation, Parsons the New School. Available online [accessed 8.2.15] http:// www.amplifyingcreativecommunities.org/AmplifyBook.pdf.

Douthwaite, R. (1996). Short Circuit: Strengthening Local Economies for Security in an Unstable World. Totnes (UK): Green Books.

Dubberly, H. (2008). Design in the Age of Biology. Interactions. XV.5: 35-41.

Dunne, A. \& Raby, F. (2013). Speculative Everything: Design, Fiction and Social Dreaming. Cambridge (MA): The MIT Press.

Escobar, A. (1995). Encountering Development: The Making and Unmaking of the Third World. Princeton (ID): Princeton University Press.

Forlizzi, J. (2007). The Product Ecology: Understanding Social Product Use and Supporting Design Culture. International Journal of Design. 1 (1): 11-20.

Gardiner, M. E. (2000). Critiques of Everyday Life. London (UK): Routledge.

Gibson, J. J. (2015). The Ecological Approach to Visual Perception. New York (NY): Psychology Press.

Gladwell, Ma. (2000). The Tipping Point. Boston (MA): Little, Brown and Company.

Hargreaves, T.; Longhurst, N. \& Seyfang, G. (2012). Understanding Sustainability Innovations: Points of Intersection Between the Multi-Level Perspective and Social Practice Theory. Norwich (UK): UEA Science, Society and Sustainability (3S) Research Group. Available online [accessed 8.2.15] https://www.academia.edu/3057996/UNDERSTAN DING_SUSTAINABILITY_INNOVATIONS_POINTS_OF_INTERSECTION_BET WEEN_THE_MULTI-LEVEL_PERSPECTIVE_AND_SOCIAL_PRACTICE_THEORY.

Highmore, B. (2002). The Everyday Life Reader. London (UK): Routledge.

Hoffman, N. (2007). Goethe's Science of Living Form: The Artistic Stages. Hillsdale (NY): Adonis Books.

Hopkins, R. (2008). The Transition Town Handbook: From Oil Dependency to Local Resilience. White River Junction (VT): Chelsea Green Publishing Company.

Hughes, K.; Fidler, S.; McGaffey, A. \& Audenried, C. (2009). Fitwits: Designed to help physicians start conversations with families about obesity. Beijing: Presented at ICOGRADA International Design Conference, October. [accessed 8.1.15]. http://repository.cmu. edu/design/1/. 
Illich, I. (1987). Toward a History of Needs. Berkeley (CA): Heyday Books.

Irwin, T. Forthcoming July 2015. Transition Design: A Proposal for a New Area of Design Practice, Research and Study. Design and Culture Journal. 7(2). London (UK) Bloomsbury. . (2015). Academia.edu [accessed 8.2.15] https://cmu.academia.edu/TerryIrwin. . (2011a). Wicked Problems and the Relationship Triad. In: Harding, Stephan, ed. Grow Small, Think Beautiful. Edinburgh (UK): Floris Books. . (2011b). Design for a Sustainable Future. In: Hershauer, J., Basile, G., McNall, S., eds., The Business of Sustainability: Trends, Policies, Practices and Stories of Success. Santa Barbara (CA): Praeger. pp. 41-60.

Jegou, F. (2015). Social Innovation in Cities. Saint Denis (FR): URBACT. http://urbact.eu/ sites/default/files/03_socialinn-web.pdf.

Jones, P. (2014). Systemic Design Principles for Complex Social Systems. In: Metcalf, Gary S., ed., Social Systems and Design. Tokoyo (Japan): Springer. pp. 91-128.

Junginger, S. (2014). Towards Policymaking as Designing: Policymaking Beyond Problemsolving and Decision-making. In: Bason, Christian ed., Cooper, Rachel, series ed., Design for Policy. Farnham (UK): Gower Publishing Limited. pp. 57-69.

Kamenetsky, M. (1992). Human Needs and Aspirations. In Ekins, Paul, Max-Neef, Manfred eds. Real-Life Economics: Understanding Wealth Creation. London (UK): Routledge.

Kasser, T. (2011). Ecological Challenges, Materialistic Value and Social change. In BiswasDiener, Robert, (ed.). Positive Psychology as Social Change. New York (NY): Springer.

Kearney, M. (1984). Worldview. Novato (CA): Chandler and Sharp.

Kemp, R. \& Loorbach, D. (2006). Transition Management: A Reflexive Governance Approach. Reflexive Governance for Sustainable Development. Northampton (MA): Edward Elgar. pp. 103-130.

Korten, D. (1999). The Post Corporate World: Life AfterCapitalism. San Francisco (CA): Berrett- Koehler Publishers, Inc.

Korten, D. (2010). Agenda for a New Economy: From Phantom Wealth to Real Wealth. San Francisco (CA): Berrett-Koehler Publishers, Inc.

Koskinen, I.; Zimmerman, J.; Binder, T.; Redstrom, J.; \& Wensveen, S. (2011). Design Research Through Practice: From the Lab, Field and Showroom. Waltham (MA): Morgan Kaufmann/Elsevier.

Kossoff, G. (2015). Academia.edu [accessed 8.2.15] https://independent.academia.edu/ GideonKossoff.

. (2011). Holism and the Reconstitution of Everyday Life: A Framework for Transition to a Sustainable Society. In: Harding, Stephan, ed. Grow Small, Think Beautiful. Edinburgh (UK): Floris Books.

Kuhn, T. (2012). The Structure of Scientific Revolutions. Chicago: University of Chicago Press.

Lefebvre, H. (1984). Everyday Life in the Modern World. Trans. Rabinovitch, S. New Brunswick (NJ): Transaction Publishers.

Lefebvre, H. (1991). Critique of Everyday Life. Trans. Moore, John. London (UK): Verso.

Linderman, A. (2012). Why the World Around You Isn't as it Appears. Aurora (CO): Lindisfarne.

Mander, J. (2012). The Capitalism Papers: Fatal Flaws of an Obsolete System. Berkeley (CA): Counterpoint. 
Manzini, E. (2015). Design When Everybody Designs. London (UK): The MIT Press.

Manzini, E. (2009). A Cosmopolitan Localism: Prospects for a Sustainable Local Development and the Possible Role of Design. Clark, Hazel, Brody, David eds. Design Studies: A Reader. New York (NY): Berg.

Manzini, E. \& Jegou, F. (2003). Sustainable Everyday: Scenarios of Urban Life. Milan (IT): Edizioni Ambiente srl. Available online [accessed 8.2.15] http://www.sustainableeveryday-project.net/blog/library-sustainable-everyday/.

Martin, B. \& Hanington, B. (2012). Universal Methods of Design: 100 Ways to Research Complex Problems, Develop Innovative Ideas, and Design Effective Solutions. Beverly (MA): Rockport Publishers.

Max-Neef, M. A. (1992). Human Scale Development: Conception, Application and Further Reflections. New York (NY): Apex. Available online [accessed 8.1.15] http://www.area-net. org/fileadmin/user_upload/papers/Max-neef_Human_Scale_development.pdf.

Meadows, D. H. (2008). Thinking in Systems, A Primer. White River Junction (VT): Chelsea Green Publishing.

Meroni, A. \& Sangiorgi, D. (2011). Design for Services. Farnham (UK): Gower. . (2007). Creative Communities: People inventing sustainable ways of living. Milan (IT): Edizioni Poli.design. http://www.strategicdesignscenarios.net/creativecommunities-book/.

Michael, M. (2012). What are we busy doing? Engaging the Idiot. Science, Technology and Human Values. 37 (5): 528-554.

Norman, D. (2004). Emotional Design: Why We Love (or Hate) Everyday Things. New York (NY): Basic Books. . (2002). The Design of Everyday Things. New York (NY): Basic Books.

Orr, D. (2004). Earth in Mind: On Education, Environment and the Human Prospect. Washington DC: Island Press.

Papanek, V. (1995). The Green Imperative: Ecology and Ethics in Design and Architecture. London (UK): Thames and Hudson.

Parker, S. \& Heapy, J. (2006). The Journey to the Interface: How Public Service Design can Connect Users to Reform. London (UK): Demos.

Penin, L. \& Manix, R. (2012). Beyond the Service Journey: How Improvisation Can Enable Better Services and Better Service Designers. In Touchpoint The Journal of Service Design. 4 (2). Service Design Network, Cologne.

Pierce, J.; Sengers, P.; Hirsch, T.; Jenkins, T.; Gaver, W. \& DiSlavo, C. (2015). Expanding and Refining Design and Criticality in HCI. In Proceedings of the 33rd Annual ACM Conference on Human Factors in Computing Systems. ACM. pp. 2083-2092.

Polaine, A.; Lovlie, L. \& Reason, B. (2013). Service Design: From Insight to Implementation. New York (NY): Rosenfeld Media.

Porritt, J. (2013). The World We Made: Alex McKay's Story from 2050. New York (NY): Phaidon Press Limited.

Prigogine, I. \& Stengers, I. (1994). Order out of Chaos: Man's New Dialogue with Nature. New York (NY): Random House.

Prochaska, J. \& Velicer, W. (1997). The Transtheoretical Model of Health Behavior Change. American Journal of Health Promotion. 12 (1): 38-48. 
Raskin, P.; Banuri, T.; Gallopin, G.; Gutman, P.; Hammond, A.; Kates, R. \& Swart, R. (2002). The Great Transition: The Promise and Lure of the Times Ahead. Stockholm (SW): Stockholm Environmental Institute and Boston (MA): Tellus Institute. [accessed 8.1.15] http://www.world-governance.org/spip.php?article90\&lang=en.

Ravetz, J. R. (2007). Post-Normal Science and the Complexity of Transitions Towards Sustainability. Ecological Complexity. 3: 275-284. Available online [accessed 8.2.15] http:// www.jerryravetz.co.uk/essays/e07postnorm.pdf.

Reilly, D.; Voida, S.; McKeon, M.; Le Dantec, C.; Bunde-Pedersen, J.; Edwards, K.; Mynatt, E.D. \& Mazalek, A. (2010). Space Matters: Physical-Digital and Physical-Virtual Codesign in inSpace. Pervasive Computing, IEEE, 9 (3): 54-63.

Rittel, Horst W. J. \& Webber, M. M. (1973). Dilemmas in a General Theory of Planning. Policy Sciences. 4: 155-169.

Sachs, W. (1999). Planet Dialectics: Exploration in Environment and Development. London (UK): Zed Books Ltd. pp. 105-107.

Saco, R. M. \& Goncalves, A. P. (2010). Service Design: An Appraisal. Design Management Review. 19 (1): 10-19.

Sangiorgi, D. (2011). Transformative services and transformation design. International Journal of Design 5.2: 29-40.

Scott, J. C. (1999). Seeing Like a State: How Certain Schemes to Improve the Human Condition Have Failed. New Haven (CT): Yale University Press.

SDN, Service Design Network. (2015). Cologne (DE): Service Design Network Office; [accessed 2015 July 28]. http://www.service-design-network.org/contact/.

Seamon, D. (1998). Goethe's Way of Science: A Phenomenology of Nature. New York (NY): State University of New York Press.

Shove, E. (2007). The Design of Everyday Life. London (UK): Berg.

Shove, E. (2009). Time, Consumption and Everyday Life: Practice, Materiality and Culture. London (UK): Bloomsbury.

Shove, E. (2010). Beyond the ABC: Climate Change Policy and Theories of Social Change. Environment and Planning. 42 (6): 1273-1285. Available online [accessed 8.2.15] http:// action-town.eu/wp-content/uploads/2010/02/BEYONDTHEABCrevised1.pdf.

Simon, H. A. (1999). Third ed. The Sciences of the Artificial. London (UK): The MIT Press. Siodmok, A. (2014). Tools for Insight: Design Research for Policymaking. In: Bason, Christian ed., Cooper, Rachel, series ed., Design for Policy. Farnham (UK): Gower Publishing Limited. pp. 191-199.

Staszowski, E.; Brown, S. \& Winter, B. (2014). Reflections on Designing for Social Innovation in the Public Sector: A Case Study in New York City. In: Bason, C., ed., Design for Policy. Farnham (UK): Gower Publishing Limited. pp. 155-165.

Stickdorn, M. \& Schneider, J. (2010). This is Service Design Thinking. Amsterdam (NL): BIS Publishers. p. 29.

Suchman, L. A. (2006). Human-Machine Reconfigurations: Plans and Situated Actions. Cambridge (UK): Cambridge University Press.

Tarnas, R. (2010). The Greater Copernican Revolution and the Crisis of the Modern World View. In Lorimer, David, Robinson, Oliver (eds). A New Renaissance: Transforming Science, Spirit and Society. Edinburgh (UK): Floris. 
Thackara, J. (2013). Forward. In: Walker, Stuart, Giard, Jacques, The Handbook of Design for Sustainability. London (UK): Bloomsbury Academic. pp. xxv - xxvi.

Tonkinwise, C. (2015). Academia.edu. [accessed 8.2.15] https://cmu.academia.edu/camerontonkinwise.

Toulmin, S. (1990). Cosmopolis: The Hidden Agenda of Modernity. New York (NY): Free Press. Verbeek, P-P. \& Slob, A. (2006). User Behavior and Technology Development. Dordrecht $(\mathrm{NL})$ : Springer.

Wheatley, M. (2006). Resilience. Leadership and the New Science: Discovering Order in a Chaotic World. San Francisco (CA): Berrett-Koehler Publishers, Inc.

Whicher, A. \& Swiatek, P. (2015). Service Design Policy Trends 2015-2020: Design-driven innovation at European, national and regional levels. SDN. [accessed 2015 July 28] http:// www.service-design-network.org/tp_7-1_p16-service-design-policy-trends-2015-2020/.

Winterhouse Institute. (2015). Social Design Pathways. [accessed 8.1.15]. http://www. socialdesignpathways.com/.

Resumen: El siguiente documento tiene como objetivo proporcionar algo de la historia y la teoría del diseño que se está utilizando en la Escuela de Diseño de la Universidad Carnegie Mellon en su esfuerzo por constituir la práctica del Diseño para la Transición. Explica cómo la profesión y la disciplina del diseño están experimentando una rápida expansión y transformación que permiten un rico conjunto de marcos para el Diseño para la Transición. Este artículo argumenta que los diseñadores no solo pueden y deben aprender de los estudios para la transición, sino que el diseño puede contribuir recíprocamente a través de nuevos enfoques para enmarcar problemas relacionados con el cambio sociotécnico dentro del contexto de ecosistemas complejos.

Palabras clave: Diseño de transición - Estudios de transición - Historia y teoría del diseño - Cambios sociotécnicos - Ecosistemas complejos.

Resumo: O documento a seguir tem como objetivo fornecer um pouco da história e da teoria do design que está sendo usada na Escola de Design da Universidade Carnegie Mellon em seu esforço para constituir a prática do Design for Transition. Explique como a profissão e a disciplina de design estão passando por uma rápida expansão e transformação que permite um rico conjunto de estruturas para o Design for Transition. Este artigo argumenta que os designers não apenas podem e devem aprender com os estudos de transição, mas que o design pode contribuir reciprocamente por meio de novas abordagens para enquadrar problemas relacionados à mudança sociotécnica no contexto de ecossistemas complexos.

Palavras chave: Projeto de transição - Estudos de transição - História e teoria do projeto - Mudanças sociotécnicas - Ecossistemas complexos. 